\title{
Pengaruh Pupuk Organik terhadap Pertumbuhan dan Hasil Tanaman Kale (Brassica oleracea acephala) Sistem Vertikultur
}

\author{
Albertus Siga Laki, Maria Aditia Wahyuningrum, dan Reni Nurjasmi \\ Program Studi Agroteknologi Fakultas Pertanian Universitas Respati Indonesia Jakarta \\ Email: asislaki@gmail.com
}

\begin{abstract}
ABSTRAK
Tanaman kale merupakan tanaman suku Brassicaceae atau kubis-kubisan yang kaya vitamin A, vitamin B1, vitamin B2, vitamin B3, vitamin C. Kale juga mengandung senyawa isotiosianat yang memiliki aktivitas antikanker. Penelitian dilaksanakan di Kebun Percobaan Fakultas Pertanian Universitas Respati Indonesia pada bulan Februari sampai dengan Agustus 2021. Rancangan yang digunakan adalah Rancangan Acak Kelompok dengan satu faktor yaitu jenis pupuk organik terdiri dari empat perlakuan yaitu pupuk NPK, kulit bawang merah, kotoran kelinci, kotoran burung. Setiap perlakuan diulang lima ulangan, sehingga diperoleh 20 unit percobaan. Variabel penelitian meliputi tinggi tanaman, jumlah daun, berat akar, panjang akar, diameter batang, dan berat basah tanaman. Hasil penelitian menunjukkan bahwa pupuk organik berpengaruh nyata terhadap tinggi tanaman, berat akar dan dan berat tanaman kale. Pupuk organik kotoran burung menghasilkan tinggi tanaman tertinggi yaitu 25,50 cm tetapi berbeda tidak nyata dengan kotoran kelinci. Berat akar dan berat basah tanaman kale tertinggi dihasilkan perlakuan kotoran kelinci masing-masing yaitu 2,28 gram dan 30,37 gram serta berbeda nyata dengan perlakuan lainnya.
\end{abstract}

Kata Kunci: Pupuk Organik, Kulit Bawang Merah, Kotoran Kelinci, Kotoran Burung, Tanaman Kale, Sistem Vertikultur

\section{ABSTRACT}

Kale is a plant belonging to the Brassicaceae tribe or cabbage which is rich in vitamin $A$, vitamin B1, vitamin B2, vitamin B3, vitamin C. Kale also contains isothiocyanate compounds which have anticancer activity. The research was carried out at the Experimental Garden of the Faculty of Agriculture, Universitas Respati Indonesia from February to August 2021. The design used was a Randomized Block Design with one factor, namely the type of organic fertilizer consisting of four treatments, namely NPK fertilizer, onion skin, rabbit droppings, and bird droppings. Each treatment was repeated five times, so that 20 experimental units were obtained. The research variables included plant height, number of leaves, root weight, root length, stem diameter, and plant wet weight. The results showed that organic fertilizer had a significant effect on plant height, root weight and plant weight of kale. Bird droppings organic fertilizer produced the highest plant height of $25.50 \mathrm{~cm}$ but it was not significantly different from rabbit droppings. The highest root weight and wet weight of kale were produced by rabbit manure treatment, which were 2.28 grams and 30.37 grams, respectively, and were significantly different from other treatments.

Keywords: Organic Fertilizer, Shallot Skin, Rabbit Manure, Bird Manure, Kale Plant, Verticulture System

\section{PENDAHULUAN}

Pandemi COVID 19 berdampak

negatif terhadap perekonomian global.
Beberapa negara maju tidak mampu

menahan resesi atau penurunan pertumbuhan perekonomian.Kondisi ini juga 
berdampak pada perekonomian Indonesia.

Badan Pusat Statistik (BPS) menginformasikan bahwa di tahun 2020 dari 17 lapangan usaha, sebagian besar sektor mengalami pertumbuhan negatif. Namun, tiga sektor lain sebaliknya mengalami pertumbuhan positif. Salah satu sektor yang mengalami pertumbuhan tertinggi adalah sektor pertanian sebesar $16,24 \%$. Kondisi ini menunjukkan bahwa sektor pertanian menjadi sektor strategis di tengah kesulitan finansial akibat pandemi Covid-19, bahkan berperan sebagai tulang punggung perekonomian nasional.

Khusus pada sub sektor hortikultura, tingkat pertumbuhan pada tahun 2020 baru mencapai $0,86 \%$. Persentase ini masih di bawah sub sektor tanaman pangan yaitu $9,23 \%$. Capaian sub sektor hortikultura tersebut masih bisa dioptimalkan mengingat pentingnya konsumsi sayuran dan buah untuk peningkatan gizi dan kekebalan tubuh.

Salah satu tanaman sayuran yang prospektif untuk dikembangkan di Indonesia adalah kale. Kale (Brassica oleracea acephala) merupakan tanaman sayuran yang termasuk ke dalam suku Brassicaceae atau kubis-kubisan. Kale diproduksi cukup banyak sekitar 2000 tanaman perhari karena permintaan yang tinggi dari daerah sekitar maupun luar kota. Target konsumen tanaman ini adalah supermarket dan restoran. Kale sangat digemari karena kaya vitamin $A$, vitamin $B 1$, vitamin $B 2$, vitamin B3, vitamin C, serta mengandung isotiosianat yang memiliki aktivitas antikanker seperti sulforafana [1.

Salah satu teknik budidaya yang dapat diterapkan pada lahan terbatas adalah budidaya sayuran dengan teknik vertikultur. Vertikultur merupakan teknik bercocok tanam di lahan sempit dengan memanfaatkan bidang vertikal sebagai tempat bercocok tanam yang dilakukan secara bertingkat. Budidaya sayuran di perkotaan memiliki peran penting dalam menjamin pasokan pangan berkesinambungan untuk penduduk kota. Kendala yang dihadapi untuk bercocok tanam di perkotaan adalah keterbatasan luas lahan. Dengan semakin mahalnya harga lahan di perkotaan, kepemilikan lahan menjadi sangat terbatas [2].

Kegiatan pertanian perkotaan tidak bisa lepas dari penerapan pertanian organik. Limbah perkotaan dimanfaatkan sebagai pupuk organik, sehingga tanaman yang dihasilkan lebih sehat karena bebas bahan kimia. Limbah perkotaan dapat berasal dari kulit bawang merah, kotoran kelinci, dan kotoran burung. Pupuk organik kulit bawang merah telah diaplikasikan pada tanaman bawang merah [3], cabai rawit [4] serta polikultur caisim dan cabai rawit [5]. Tujuan penelitian adalah mengetahui pengaruh pupuk organik terhadap pertumbuhan dan hasil tanaman kale serta jenis pupuk organik 
yang menghasilkan pertumbuhan dan hasil yang terbaik pada sistem vertikultur.

\section{METODE}

\section{Waktu dan Tempat}

Penelitian dilaksanakan di Kebun Percobaan Fakultas Pertanian UniversitasRespatilndonesia pada bulan Februari sampai dengan Agustus 2021.

\section{Alat dan Bahan}

Bahan-bahan yang digunakan dalam penelitian adalah benih kale, bakteri EM4, gula merah, pupuk organik kulit bwang merah, kotoran kelinci, kotoran burung, pupuk NPK, dan tanah. Alat-alat yang digunakan pada penelitian adalah pot ukuran $40 \mathrm{~cm} \times 40 \mathrm{~cm}$, rak tanaman, dan timbangan digital.

\section{Rancangan Penelitian}

Rancangan yang digunakan dalam penelitian ini adalah Rancangan Acak Kelompok (RAK), dengan satu faktor yaitu jenis pupuk organik terdiri dari empat perlakuan yaitu tanah dan NPK, pupuk kulit bawang merah, pupuk kotoran kelinci, pupuk kotoran burung yang diulang lima ulangan, sehingga diperoleh 20 unit percobaan.

\section{Cara Kerja}

Sterilisasi benih dengan merendamnya dalam air panas sekitar $55^{\circ} \mathrm{C}$ selama 15-30 menit. Rendam benih selama kurang lebih 12 jam atau sampai benih terlihat pecah dengan tujuan agar benih cepat berkecambah. Penyemaian dilakukan dengan menaruh benih di bak persemaian sedalam 0,2-1,0 cm. Media semai terdiri dari campuran ayakan pupuk kandang matang dengan tanah halus dan sekam bakar perbandingannya 1:1. Selama penyemaian, benih disiram pagi dan sore hari.

Tanah dicampur dengan pupuk sesuai perlakuan kemudian dibiarkan selama satu minggu baru. Bibit yang memiliki 3-4 helai daun atau berusia sekitar 2 minggu dipindahkan ke dalam polibag diameter $40 \mathrm{x}$ $40 \mathrm{~cm}$. Polibag tersebut disusun pada rak sesuai dengan rancangan acak kelompok.

Pemeliharaan meliputi penyulaman yaitu mengganti tanaman yang rusak atau mati. Penyulaman hanya dapat dilakukan sebelum tanaman berumur 2 minggu. Pencegahan serangan hama atau penyakit dilakukan dengan menyemprotkan pestisida organik meskipun belum ada gejala serangan hama dan memasang kasa untuk mencegah hama pemakan daun seperti belalang. Tanaman juga harus disiram pagi dan sore hari. Pemanenan dilakukan ketika tanaman kale telah berumur 35-45 hari. Kale yang sudah dipanen diletakkan di tempat yang teduh. 


\section{Variabel Penelitian}

Variabel penelitian yang diamati adalah tinggi tanaman diukur seminggu sekali, jumlah daun diukur seminggu sekali, panjang akar diukur setelah panen, diameter batang diukur setelah panen, berat akar diukur setelah panen, dan berat basah tanaman diukur setelah panen.

\section{Analisis Data}

Data hasil pengamatan diuji dengan analisa sidik ragam, bila hasil sidik ragam berbeda nyata ( $\mathrm{F}$ hitung $>\mathrm{F}$ tabel 0,05 ) atau berbeda sangat nyata ( $F$ hitung $>$ $F$ tabel 0,01). Maka untuk membandingkan dua rata-rata taraf perlakuan, dilakukan uji lanjutan dengan dan $u j i \mathrm{t}$ taraf $5 \%$. Sedangkan bila sidik ragam berbeda tidak nyata ( $F$ hitung $\leq F$ tabel 0,05 ), maka tidak dilakukan uji lanjutan. Analisis data menggunakan program SPSS.

\section{HASIL DAN PEMBAHASAN}

\section{Kandungan Unsur Hara Pupuk Organik}

Analisis kandungan unsur hara pupuk organik yang berasal dari limbah kota yaitu kulit bawang merah, kotoran kelinci, dan kotoran burung meliputi kadar air, $\mathrm{pH}$ $\mathrm{H}_{2} \mathrm{O}$, C-organik, $\mathrm{N}$-total, $\mathrm{P}_{2} \mathrm{O}_{5}$, dan $\mathrm{K}_{2} \mathrm{O}$. Tabel 1 menunjukkan hasil analisis kandungan unsur hara pupuk organik tersebut. Tabel 1 menunjukkan bahwa kotoran kelinci mengandung unsur $\mathrm{N}, \mathrm{P}$, dan $\mathrm{K}$ yang lebih kecil dibandingkan kulit bawang merah dan kotoran burung. Unsur N dan P paling tinggi terdapat pada kotoran burung sedangkan unsur hara $\mathrm{K}$ paling tinggi terdapat pada kulit bawang merah. Limbah kulit bawang saat ini semakin sering digunakan sebagai pupuk organik. Kulit bawang merah biasanya memiliki kandungan K. Pada hasil penelitian laboratorium, kulit bawang memiliki unsur $\mathrm{K}$ paling tinggi dibandingkan dengan kotoran kelinci dan kotoran burung. Kulit bawang merah mengandung Kalium, Magnesium, Fosfor dan Besi yang baik untuk pertumbuhan tanaman [6].

Tabel 1. Kandungan Unsur Hara Pupuk Organik

\begin{tabular}{lccc}
\hline \multirow{2}{*}{ Parameter } & \multicolumn{3}{c}{ Pupuk Organik } \\
\cline { 2 - 4 } & Kulit Bawang Merah & Kotoran Kelinci & Kotoran Burung \\
\hline Kadar air (\%) & 25,72 & 62,74 & 14,67 \\
pH H $\mathrm{H}_{2} \mathrm{O}$ & 4,46 & 5,26 & 8,06 \\
$\mathrm{C}$-organik (\%) & 20,08 & 34,79 & 27,21 \\
$\mathrm{~N}$-total (\%) & 2,24 & 1,76 & 2,79 \\
Rasio C/N (\%) & 8,96 & 19,77 & 9,75 \\
$\mathrm{P}_{2} \mathrm{O}_{5}(\%)$ & 1,29 & 1,78 & 5,41 \\
$\mathrm{~K}_{2} \mathrm{O}(\%)$ & 2,52 & 0,22 & 2,20 \\
\hline
\end{tabular}

Pupuk organik kulit bawang merah juga mengandung hormon giberelin dan auksin yang berguna sebagai zat pengatur tumbuh pertumbuhan. Kandungan hormon 
pada kulit bawang berupa $A B A, I A A, G A$, dan

Sitokinin, juga mengandung zat dan senyawa yang berpotensi dapat membunuh hama ulat dan mempercepat pertumbuhan pada akar [7]. Kulit bawang merah mengandung unsur $\mathrm{K}$ yang bermanfaat bagi tanaman kale agar pertumbuhan dan produksinya optimal [5]. Selain itu unsur K dalam pupuk kulit bawang sangat dibutuhkan oleh tanaman yang dapat dapat memicu pertumbuhan karena unsur $\mathrm{K}$ berfungsi sebagai zat pengatur atau perangsang tumbuh alami.

Kelinci dengan berat badan 1 kilogram akan menghasilkan 28,0 gram kotoran lunak perhari dan mengandung 3 gram protein serta 0,35 gram nitrogen dari bakteri atau setara 1,3 gram protein. Urin kelinci mengandung unsur $\mathrm{N}, \mathrm{P}$, dan $\mathrm{K}$ masing-masing sebesar lebih tinggi 2,72\%; $1,1 \% ; 0,5 \%$ daripada kotoran dan urin ternak lain seperti sapi, kerbau, domba, kuda, babi, dan ayam [8].

Pupuk organik kotoran kelinci memiliki rasio $\mathrm{C} / \mathrm{N}$ yang paling tinggi (Tabel 1). Rasio $\mathrm{C} / \mathrm{N}$ yang baik untuk pupuk berkisar 15\%-20\%. Rasio ini menandakan banyaknya Nitrogen yang tersedia dan dapat diserap oleh tanaman. Rasio yang rendah menandakan unsur hara $\mathrm{N}$ yang tersedia bagi tanaman, tetapi rentan untuk hilang dari tanah, baik dalam proses pencucian atau penguapan [9]. Pupuk kotoran kelinci sendiri dapat memperbaiki sifat fisik, biologi dan kimia tanah karena unsur organiknya dan menggemburkan tanah [10].

Pupuk organik kotoran burung merupakan pupuk yang masih jarang digunakan bila dibandingkan dengan penggunaan pupuk kandang sapi atau kambing tetapi belakang ini mulai dilirik sebagai alternatif pupuk kandang dengan nama pupuk guano, sehingga kotoran puyuh dapat dimanfaatkan daripada terbuang begitu saja. Pupuk kotoran burung sendiri tinggi dalam $\mathrm{N}$ dan $\mathrm{P}$

(Tabel 1) yang baik digunakan untuk masa vegetatif. Kotoran puyuh mengandung kadar protein tinggi serta banyak mengandung unsur hara makro maupun mikro [11]. Kotoran burung juga dikenal dengan kandungan $P$ yang tinggi, sehingga sering dijadikan pupuk sumber $\mathrm{P}$ dan dikenal dengan pupuk organik fosfor [12].

Pada pembuatan pupuk organik cair dengan bahan jerami padi, penambahan kotoran burung puyuh sebagai aktivator meningkatkan ketersediaan unsur $\mathrm{P}$ pada hasil akhir ( [13]. Selain meningkat kandungan $\mathrm{P}$, pupuk kotoran burung puyuh juga kaya akan C-organik yang membantu memperbaiki sifat tanah, membantu meningkatkan pertumbuhan aktivitas mikroorganisme tanah sehingga membantu penyerapan unsur hara oleh tanaman [14].

Pemanfaatan limbah burung tidak hanya pada kotoran saja tetapi sisa pakan juga dapat dimanfaatkan bersama dengan 
kotorannya. Limbah burung dapat dimanfaatkan menjadi pakan ternak ikan karena kadar proteinnya yang tinggi, selain itu limbah ini juga dapat dimanfaatkan sebagai pupuk organik. Hewan peliharaan yang diberikan pakan tinggi protein dan mineral akan menghasilkan kotoran tinggi $\mathrm{N}$ dan unsur mineral lainnya [15]. Hal ini yang menyebabkan pada pupuk kotoran burung tinggi pada $\mathrm{N}$ bila dibandingkan kotoran kelinci.

Dari Tabel 1 dapat dilihat bahwa kandungan $\mathrm{K}$ lebih tinggi dimiliki pada kulit bawang merah namun kandungan $\mathrm{N}$ dan $\mathrm{P}$ lebih tinggi yang berasal dari kotoran burung, sehingga bila diaplikasikan pada tanaman kale akan membantu pertumbuhan dan produksinya lebih optimal karena kecukupan unsur hara yang baik.

\section{Pengaruh Pupuk Organik terhadap} Pertumbuhan dan Hasil Tanaman Kale

Berdasarkan hasil uji statistik pupuk organik kulit bawang merah, kotoran kelinci, dan kotoran burung berpengaruh nyata terhadap tinggi tanaman, berat akar dan berat tanaman kale sedangkan terhadap jumlah daun, diameter batang, dan panjang akar pupuk organik tidak berbeda nyata. Tabel 2 menyajikan pengaruh pupuk organik terhadap pertumbuhan dan hasil tanaman kale.

Tabel 2. Pengaruh Pupuk Organik terhadap Pertumbuhan dan Hasil Tanaman Kale

\begin{tabular}{|c|c|c|c|c|c|c|}
\hline Perlakuan & $\begin{array}{c}\text { Tinggi } \\
\text { Tanaman } \\
\text { (cm) }\end{array}$ & $\begin{array}{l}\text { Jumlah } \\
\text { Daun } \\
\text { (helai) }\end{array}$ & $\begin{array}{c}\text { Diameter } \\
\text { Batang } \\
(\mathrm{cm})\end{array}$ & $\begin{array}{l}\text { Panjang } \\
\text { Akar } \\
\text { (cm) }\end{array}$ & $\begin{array}{l}\text { Berat } \\
\text { Akar } \\
\text { (gram) }\end{array}$ & $\begin{array}{c}\text { Berat } \\
\text { Tanaman } \\
\text { (gram) }\end{array}$ \\
\hline Pupuk NPK & $16.70 \mathrm{a}$ & $9.00 \mathrm{a}$ & $1.38 \mathrm{a}$ & $12.88 \mathrm{a}$ & $0.82 \mathrm{a}$ & $13.72 \mathrm{a}$ \\
\hline Kulit Bawang Merah & $18.48 \mathrm{a}$ & $11.80 \mathrm{a}$ & $2.08 \mathrm{a}$ & $14.02 \mathrm{a}$ & $2.28 \mathrm{c}$ & $30.37 c$ \\
\hline Kotoran Kelinci & $24.42 \mathrm{~b}$ & $11.00 \mathrm{a}$ & $1.92 \mathrm{a}$ & 13.18 a & $1.67 \mathrm{~b}$ & $15.23 \mathrm{a}$ \\
\hline Kotoran Burung & $25.50 \mathrm{~b}$ & $12.20 \mathrm{a}$ & $1.70 \mathrm{a}$ & $13.60 \mathrm{a}$ & $1.18 \mathrm{a}$ & $21.57 \mathrm{~b}$ \\
\hline
\end{tabular}

Keterangan: angka yang diikuti notasi huruf yang sama menunjukkan berpengaruh tidaknyata

Pengaruh Pupuk Organik terhadap Tinggi Tanaman Kale

Tabel 2 menunjukkan bahwa perlakuan pupuk organik menghasilkan tanaman kale yang lebih tinggi dibandingkan pupuk NPK. Tanaman kale paling tinggi dihasilkan perlakuan kotoran burung namun berbeda tidak nyata dengan perlakuan kotoran kelinci. Pertambahan tinggi tanaman pada pemberian kotoran burung ini sejalan dengan penelitian lain yaitu pemberian pupuk kotoran burung puyuh meningkatkan panjang tanaman, jumlah dan 
luasan daun serta berat bersih dan kotor pada tanaman sawi putih [16].

Berdasarkan hasil analisis kandungan unsur hara (Tabel 1), kotoran burung mengandung unsur hara $\mathrm{N}$ yang paling tinggi dibandingkan kulit bawang merah dan kotoran kelinci, sehingga tanaman kale yang diberi perlakuan kotoran burung akan menghasilkan tanaman yang paling tinggi dibandingkan perlakuan lainnya. Unsur hara Nitrogen merupakan salah satu unsur hara makro yang terbanyak diserap oleh tanaman dalam masa vegetatif. Pada perlakuan kotoran kelinci, pertumbuhan tinggi tanaman tidak berbeda nyata dengan kotoran burung. Hal ini dapat disebabkan oleh karena pada pupuk kotoran kelinci memiliki rasio $\mathrm{C} / \mathrm{N}$ yang tinggi sehingga $\mathrm{N}$ yang tersedia bagi tanaman cukup untuk mendukung pertumbuhan vegetatif.

Unsur Fosfor merupakan komponen penyusun dari beberapa enzim, protein, ATP, RNA, dan DNA. ATP penting untuk proses transfer energi, sedangkan RNA dan DNA menentukan sifat genetik dari tanaman. Unsur $P$ juga berperan pada pertumbuhan benih, akar, bunga, dan buah, sehingga tanaman kale yang diberi perlakuan kotoran burung akan menghasilkan tanaman yang paling tinggi dibandingkan perlakuan lainnya [17].
Pengaruh Pupuk Organik terhadap Jumlah Daun Tanaman Kale

Perlakuan pupuk organik berpengaruh tidak nyata terhadap jumlah daun namun secara umum dapat dilihat bahwa perlakuan pupuk NPK menghasilkan jumlah daun yang paling sedikit dibandingkan perlakuan pupuk organik. Perlakuan pupuk kotoran burung menghasilkan jumlah daun paling banyak dibandingkan perlakuan lainnya.

Kulit bawang merah memiliki Rasio $\mathrm{C} / \mathrm{N}$ paling rendah. Sedangkan Rasio $\mathrm{C} / \mathrm{N}$ pada kotoran kelinci dan kotoran burung puyuh cukup tinggi. Kotoran burung mengandung unsur hara $\mathrm{N}$ paling tinggi dibandingkan limbah kulit bawang merah dan kotoran kelinci. Nitrogen merupakan unsur hara esensial bagi tanaman sehingga kekurangan nitrogen dapat menyebabkan tanaman tidak dapat tumbuh dengan normal. Unsur $\mathrm{N}$ merupakan unsur hara essensial yang termasuk ke dalam unsur hara makro diperlukan dalam jumlah banyak. $\mathrm{N}$ juga berfungsi untuk membantu pembentukan klorofil, protein dan asam amino [18]. Fungsi unsur nitrogen yaitu untuk memperbaiki pertumbuhan vegetatif tanaman dan pembentukkan [19]. Unsur $\mathrm{N}$ membantu pertumbuhan vegetatif tanaman berupa daun, sehingga jumlah daun yang dihasilkan kotoran burung juga lebih banyak dibandingkan perlakuan kulit bawang merah dan kotoran kelinci. 
Peningkatan pembentukan klorofil akan menyebabkan proses fotosintesis pun ikut meningkat yang mempengaruhi perkembangan meristem pada daun [20]. Kondisi ini juga membantu peningkatan jumlah daun pada kotoran burung.

\section{Pengaruh Pupuk Organik terhadap}

\section{Diameter Batang Tanaman Kale}

Perlakuan pupuk organik berpengaruh tidak nyata terhadap diameter batang namun secara umum dapat dilihat bahwa perlakuan pupuk NPK menghasilkan diameter batang yang paling kecil dibandingkan perlakuan pupuk organik. Pupuk organik kulit bawang merah menghasilkan diameter batang paling besar dibandingkan perlakuan lainnya.

Pupuk organik kulit bawang merah mengandung unsur hara $\mathrm{K}$ paling tinggi dibandingkan kotoran kelinci dan kotoran burung sehingga diameter batang yang dihasilkan kulit bawang merah juga lebih besar dibandingkan kotoran kelinci dan kotoran burung. Unsur hara kalium pada tanaman berfungsi untuk meningkatkan pertumbuhan jaringan meristem dan mengatur pergerakan stomata. Pertumbuhan diameter ini kemungkinan dikarenakan oleh perkembangan jaringan meristem yang lebih cepat akibat tingginya unsur hara $\mathrm{K}$ pada perlakuan kulit bawang merah, sehingga diameter tanaman menjadi lebih besar dibandingkan perlakuan lainnya.
Hormon sitokinin adalah hormon yang mempunyai fungsi utama mensupport pertumbuhan tunas dan batang. Sitokinin berfungsi untuk memacu pembelahan sel dalam jaringan meristematik, merangsang diferensiasi sel-sel yang dihasilkan dalam meristem, mendorong pertumbuhan tunas samping, dominasi apikal dan perluasan daun [21], sehingga diameter batang yang dihasilkan kulit bawang merah juga lebih besar dibandingkan perlakuan kotoran kelinci dan kotoran burung.

\section{Pengaruh Pupuk Organik terhadap Panjang} Akar Tanaman Kale

Unsur hara Kalium berperan penting dalam pertumbuhan tanaman, terutama dalam pupuk organik kulit bawang merah mengandung unsur hara $\mathrm{K}$ paling tinggi dibandingkan kotoran kelinci dan kotoran burung sehingga akar yang dihasilkan kulit bawang merah juga lebih panjang dibandingkan perlakuan kotoran kelinci dan kotoran burung. Unsur $\mathrm{K}$ sendiri berfungsi juga untuk mempengaruhi peningkatan pertumbuhan jaringan meristem. Terdapat tiga jenis jaringan meristem pada tanaman, yaitu lateral, interkalar dan apikal. Pada meristem apikcal, pembelahan sel terbentuk pada ujung ujung tanaman seperti pada tunas dan akar. Dengan tingginya pembelahan meristem apical, maka juga mempercepat pertumbuhan ujung akar yang berakibat pada pertumbuhan Panjang akar 
yang lebih baik dibandingkan perlakuan lainnya [22].

Perlakuan pupuk organik berpengaruh tidak nyata terhadap panjang akar karena tidak terlalu jauh perbedaan panjangnya. Pupuk organik kulit bawang merah menghasilkan akar yang lebih panjang dibandingkan perlakuan lainnya karena aplikasi pupuk bagi tanaman kale berasal dari kulit bawang merah sedangkan pada perlakuan kotoran kelinci dan kotoran burung tidak ada perbedaan yang signifikan pada panjang akar terlebih dengan perlakuan pupuk NPK. Pupuk organik kulit bawang merah mengandung unsur hara $\mathrm{K}$ paling tinggi dibandingkan kotoran kelinci dan kotoran burung sehingga akar yang dihasilkan kulit bawang merah juga lebih panjang dibandingkan perlakuan kotoran kelinci dan kotoran burung.

Kulit bawang merah memiliki unsur hara kandungan $\mathrm{K}$ yang lebih tinggi dikarenakan terdapat zat pengatur tumbuh alami yang tidak dimiliki pada kotoran kelinci ataupun burung puyuh [5]. Sehingga mengandung zat dan senyawa yang berpotensi dapat mempercepat petumbuhan pada akar [7]. Hormon auksin akan merangsang sel-sel terus membelah dan membentuk primordia akar. Dengan terbentuknya primordia akar maka akar sudah dapat menyerap unsur hara dari media sehingga merangsang pertumbuhan tunas, jumlah tunas dan persentase pertumbuhan tunas [23].

Auksin merupakan zat pengatur tumbuh yang beperan dalam pemanjangan sel. Keberadaan hormon ini dapat merangsang pembentukan dan pertumbuhan akar tanaman kale. Kinerja hormon auksin ini dapat meningkat dengan bantuan unsur P. Kinerja auksin dapat meningkat dengan adanya unsur fosfor yang tinggi sehingga pertumbuhan akar dapat berlangsung secara optimal [24]. Sehingga akar yang dihasilkan perlakuan kulit bawang merah juga lebih panjang dibandingkan perlakuan kotoran kelinci dan kotoran burung. Selain itu pupuk kulit bawang juga mengandung hormone giberelin [28]. Pemberian giberelin (GA3) memberi pengaruh terhadap pertambahan Panjang akar kalian [25]. Lokasi pemberian sangat berpengaruh terhadap proses kerjanya [26]. Sebagai contoh, apabila menginginkan pertumbuhan tunas yang banyak, sebaiknya diberikan secara disemprot pada tunas. Pada penelitian, pupuk kulit bawang merah diberikan pada tanah sehingga hormon lebih banyak berinteraksi dengan akar tanaman yang menyebabkan pertambahan Panjang akar tanaman. Hal-hal inilah yang mungkin membuat panjang akar kale pada perlakuan kulit bawang merah lebih panjang dari perlakuan lainnya. 
Pengaruh Pupuk Organik terhadap Berat Akar Tanaman Kale

Perlakuan pupuk organik berpengaruh nyata terhadap berat akar tanaman kale secara umum dapat dilihat bahwa perlakuan kulit bawang merah menghasilkan berat akar yang paling besar dibandingkan kotoran kelinci dan kotoran burung serta pupuk NPK. Pupuk organik kulit bawang merah menghasilkan akar yang paling berat dibandingkan perlakuan lainnya. hal ini terjadi karena unsur $\mathrm{K}$ pada kulit bawang merah yang tinggi, unsur $\mathrm{K}$ berfungsi juga untuk mempengaruhi peningkatan pertumbuhan jaringan meristem. Pembelaan meristem apikal mempercepat pertumbuhan ujung akar yang berakibat pada pertumbuhan Panjang akar yang lebih baik dibandingkan perlakuan lainnya [22].

Kulit bawang juga mengandung Auksin dan Gieberelin. Auksin memiliki fungsi utama dalam mensupport pertumbuhan akar dan giberelin memiliki fungsi untuk menunjang pembelahan sel akar dan tunas [23]. Kedua hal inilah yang menyebabkan berat akar pada pupuk organik kulit bawang merah lebih tinggi dibandingkan dengan perlakuan lainnya. Pupuk organik kotoran burung juga mengandung unsur $\mathrm{N}$ paling tinggi dibandingkan kulit bawang merah dan kotoran kelinci, sehingga akar yang dihasilkan perlakuan kotoran burung juga lebih berat dibandingkan kulit bawang merah dan kotoran kelinci.

\section{Pengaruh Pupuk Organik terhadap Berat Basah Tanaman Kale}

Tabel 2 juga menunjukkan bahwa perlakuan pupuk organik menghasilkan berat tanaman kale yang lebih tinggi dibandingkan pupuk NPK. Berat tanaman kale paling tinggi dihasilkan perlakuan kulit bawang merah dan berbeda nyata dengan perlakuan lainnya kemudian diikuti dengan kotoran burung yang menghasilkan tanaman kale yang lebih berat dibandingkan pupuk NPK dan kotoran kleinci.

Berat segar tanaman dipengaruhi
oleh biomassa tanaman. Biomassa
merupakan ukuran hasil dari pertumbuhan tanaman dari reaksi biokimia yang diawali dari penyusunan sel yang akan membentuk jaringan kemudian akan membangun organ hingga pada akhirnya membentuk tubuh tanaman [24]. Dengan penguatan jaringan meristem maka tanaman akan semakin besar. Berat tanaman didukung oleh besar diameternya dan juga banyaknya jumlah organ tanaman tersebut. Pada pupuk organik limbah kulit bawang merah, diameter tanaman dan berat akar tertinggi dibandingkan perlakuan lainnya, sehingga membuat berat total tanamannya menjadi lebih besar dibandingkan yang lainnya.

Unsur hara dan hormon merupakan hal yang penting bagi pertumbuhan 
tanaman. Untuk meningkatkan pertumbuhan tanaman, pupuk dan hormone dapat diberikan agar memberikan hasil yang terbaik. Akan tetapi, pemberian pupuk pada tanaman sebaiknya memperhatikan keseimbangannya, karena beberapa unsur hara dan hormon tumbuhan memiliki sifat yang saling menekan, misalnya unsur $\mathrm{K}$ baik bagi pertumbuhan tanaman, tetapi dapat menekan penggunaan Kalsium dan Magnesium pada pertumbuhan tanaman. Selain itu pemberian pupuk yang berlebih juga tidak memberikan hasil yang positif bagi pertumbuhan tanaman.

Jumlah daun, diameter batang, dan panjang akar pada penelitian ini tidak sesuai dengan kriteria ideal tanaman kale saat panen. Diduga jarak tanam yang kurang tepat dapat menyebabkan persaingan unsur antar tanaman, baik unsur hara, sinar matahari, ataupun air [25]. Tanaman kale dapat tumbuh optimal di tempat dengan suhu udara berkisar antara $15^{\circ} \mathrm{C}-20^{\circ} \mathrm{C}$ dan kelembaban relatif udara antara 80-90\% [26].

\section{KESIMPULAN}

Pupuk organik kotoran burung menghasilkan tinggi tanaman tertinggi yaitu $25,50 \mathrm{~cm}$ tetapi berbeda tidak nyata dengan kotoran kelinci. Berat akar dan berat basah tanaman kale tertinggi dihasilkan perlakuan kotoran kelinci masing-masing yaitu 2,28 gram dan 30,37 gram serta berbeda nyata dengan perlakuan lainnya.

\section{DAFTAR PUSTAKA}

Dalmadi. 2010. Syarat Tumbuh Brokoli. Direktorat Jenderal Holtikultura. Jakarta.

Suryani, Reni, N., Siti, S.M., dan Ayu, V.C.K. 2017. Pelatihan Pertanian Perkotaan. Jurnal Pelayanan Dan Pengabdian Masyarakat. 1(1): 69-81.

Tamot, A. dan Suryani. 2019. Pengaruh Pupuk Kandang Kelinci dan Jumlah Bibit Per Polibag terhadap Pertumbuhan dan Hasil Tanaman Bawang Merah (Allium ascolonicum L.). Jurnal IImiah Respati. 10(2): 79-90.

Adam, S. Y. Y., R. Nurjasmi., dan L. S. Banu. 2019. Pengaruh Kompos Kulit Bawang Merah dan Pupuk NPK terhadap Pertumbuhan Tanaman Cabe Rawit (Capsicum frutescens L.). Jurnal IImiah Respati. 10(2): 146-155.

Yikwa, P. dan Banu, L.S. 2020. Respon Polikultur Cabai Rawit dan Sawi terhadap Waktu Pengomposan dan Dosis Kompos Kulit Bawang Merah. Jurnal Ilmiah Respati. 11(1): 46-61.

Rahmawati, D. 2020. Pemanfaatan Kulit Bawang Merah untuk Tanaman. http://cybex.pertanian.go.id/mobile/a rti kel/94229/Pemanfaatan-kulitbawangmerah-untuk-tanaman. 
Rifani, A.N. 2015. Pengaruh Larutan Kulit

Bawang Merah (Allium cepa L.) terhadap Pertumbuhan Akar Stek Batang Sirih Merah (Piper crocatum). Thesis. IAIN Palangka Raya.

Sumarni, S., Sukatiman, E. Sri, dan A. Adenata. 2015. Usaha Budidaya Kelinci Terpadu. Prosiding Seminar Nasional 4th UNS SME's Summit dan Awards Tahun 2015.

Suhastyo, A.A. dan F.T. Raditya. 2017. Respon Pertumbuhan Tanaman Pakcoy (Brassica chinensis L.) Terhadap Pemberian Pupuk Organik Cair MOL dan Pupuk Kotoran Kelinci. Media Agrosains. 3(1): 14-18.

Rohmawati, F.A., R. Soelistyono, dan Koesriharti. 2017. Pengaruh Pemberian PGPR (Plant Growth Promoting Rhizobacteria) dan Kompos Kotoran Kelinci Terhadap Hasil Tanaman Terung (Solanum melongena L.). Jurnal Produksi Tanaman. 5(8): 1294-1300.

Ramaiyulis dan Nilawati. 2009. Buku Ajar Bahan Protein dan Formulasi. Ransum. Politeknik Pertanian Negeri Payakumbuh.

Syahendra, F., J. Hutabarat, dan V.E. Herawati. 2016. Pengaruh Pengkayaan Bekatul dan Ampas Tahu dengan Kotoran Burung Puyuh yang Difermentasi Dengan Ekstrak Limbah Sayur Terhadap Biomassa dan
Kandungan Nutrisi Cacing Sutera (Tubifex sp.) Journal of Aquaculture Management and Technology. 5(1): 35-44.

Qomariyah, Nisaa dan, A. Asngad. 2017. Uji Kandungan Nitrogen dan Phospor Pupuk Organik Cair Kombinasi Jerami Padi dan Daun Kelor dengan Penambahan Kotoran Burung Puyuh sebagai Bioaktivator. Skripsi thesis. Universitas Muhammadiyah Surakarta.

Siregar, F. 2020. Pengaruh Pemberian Kotoran Burung Puyuh dan Ekstrak Kulit Pisang terhadap Pertumbuhan dan Produksi Kedelai (Glycine soja). Skripsi. Fakultas Pertanian Universitas Muhammadiyah Sumatera Utara. Medan.

Setyamidjaja, D. 1986. Pupuk dan Pemupukan. Penerbit CV Simplek. Jakarta.

Kusuma, M. E. 2012. Pengaruh Takaran Pupuk Kandang Kotoran Burung Puyuh terhadap Pertumbuhan dan Hasil Tanaman Sawi Putih (Brassica juncea L.). Jurnal Ilmu Hewani Tropika (Journal of Tropical Animal Science). 1(1): 7-11.

Handiyono dan Zulkarnain. 1992. Tanggap Pertumbuhan dan Produksi Melon (Cucumis melo) terhadap Takaran Pupuk N, P, K. Majalah Ilmiah Universitas Jambi. Jambi. 28: 53 - 64. 
Mukhlis. 2017. Unsur Hara Makro dan Mikro yang Dibutuhkan oleh Tanaman. Dinas Pertanian Kabupaten Luwu Utara. https://dtphp.luwuutarakab.go.id/ber ita/3/unsur-hara-makro-dan-mikroyang-dibutuhkan-oleh tanaman.html?fb_comment_id=3189 773321086078_3795980587132012.

Diakses tanggal 15 Agustus 2021.

Hardjowigeno, S \& M.L.Rayes, 2001. Tanah Sawah. Program Pascasarjana IPB, Bogor.

Molnar, Z., E. Virag, and V. Ordog. 2011. Natural Subtances in Tissue Culture Media of Higher Plants. Acta Biologica Szegediensis. 55(1): 126-127.

Wicaksono, F.Y., Putri, A.F., Yuwariah, Y., Maxiselly, Y., dan Nurmala, T. 2017. Respons Tanaman Gandum Akibat Pemberian Sitokinin Berbagai Konsentrasi dan Waktu Aplikasi di Dataran Medium Jatinangor. Jurnal Kultivasi. 16(2): 349-355.

Ramdhini, R.N., A.I. Manalu, I.P. Ruwaida, P.L. Isrianto, N.H. Panggabean, S. Wilujeng, I.E., S.R.F. Purba, E. Sutrisno, I.L. Hulu, S. Purwanti, B. Utomo, D.R. Surjaningsih. 2021. Anatomi Tumbuhan. Yayasan Kita Menulis. Medan.

Hutahayan, A.J. 2015. Pengaruh Konsentrasi dan Lama Perendaman dengan Zat Pengaruh Tumbuh IBA terhadap
Pertumbuhan Stek Tanaman Jeruk. Jurnal Wahana Inovasi. 4 (2).

Sakya, A. T., D. Purnomo, dan F. Fahrudin. 2009. Penggunaan Ekstrak Teh Dan Pupuk Kascing Pada Budidaya Caisim (Brassica juncea L.). J. IImiah IImu Tanah dan Agroklimatologi. 6(2) : 6168.

Maharani, A., Suwirmen, Z.A. Noli. 2018. Pengaruh Konsentrasi Giberelin (GA3) terhadap Pertumbuhan Kailan (Brassica oleracea L. var. alboglabra) pada Berbagai Media Tanam dengan Hidroponik Wick System. Jurnal Biologi Universitas Andalas. 6 (2): 6370.

Kurnia, M. 2014. Hormon Tumbuhan. https://distan.bulelengkab.go.id/infor masi/detail/artikel/hormontumbuhan-77. Diakses pada 14 Agustus 2021.

Advinda L. 2018. Dasar-Dasar Fisiologi Tumbuhan. Deepublish. Yogyakarta.

Sajid, F. 2016. Aplikasi Briket GliricidaeArang Sekam dalam Upaya Meningkatkan Efisiensi Pemupukan Tanaman Tomat (Lycopersicum Esculentum L.) di Lahan Terpapar Erupsi Merapi 2010. Skripsi. Fakultas Pertanian Universitas Muhammadiyah Yogyakarta. Yogyakarta.

Vidianto, D, Z., S. Fatimah, dan C. Wasonawati. 2013. Penerapan Panjang Talang dan Jarak Tanam 
Jurnal IImiah Respati

\author{
dengan Sistem Hidroponik NFT \\ (nutrient film technique) pada \\ tanaman kalian (Brassica oleraceae \\ var. alboglabra). J. Agrovigor. 6 (2) : \\ 128-135.
}

Nugrahini, T., A. Wati, dan D. Indriani. 2018.

Kajian Penggunaan Biourine Sapi dan

Ekstrak Bawang Merah terhadap Sifat

Agronomi Tanaman Kubis (Brassica

oleracea L.) Dataran Rendah. J.

Agrifarm. 7 (2): 63-69. 